\title{
Happiness Of Oil And Gas Industry Employees In Relations To Productivity:Abu Dhabi, UAE
}

\author{
Naser Yassin Al Hammadi, Md Asrul Nasid Bin Masrom, Sulzakimin Mohamed
}

\begin{abstract}
In recent years, oil and gas industries in the United Arab Emirates (UAE) experienced economic challenges brought about by changes happening in the world market. Consequently, given the economic challenges and the instability of the oil and gas sector in the UAE, the level of happiness of the employees may somehow be negatively affected. Nowadays, different companies not only oil and gas industry pose a great challenge towards happiness of employees. Study on employees' happiness has recently gained much attention due to its emphasis in organizational studies and the impact it has on overall employee performance. This research study aims to investigate and critically assess the common attributes that affects happiness of employees in the oil and gas industry in Abu Dhabi, UAE. In addition, this study intends to examine the relationship between happiness of employees and productivity in the said sector in the midst of the present challenges happening in the oil and gas sector in the Middle East region. Essentially, this research consists of two main objectives which include: (1) To identify the internal and external factors affecting the happiness of employees, and (2) To investigate how these factors related to employee's productivity. To achieve the aims of this research, a quantitative research method will be applied in this study. Specifically, a survey research will be used to gather data who are mainly present employees on the selected oil and gas company in Abu Dhabi, UAE. Findings will be tabulated and analyzed in relation to the objectives of the study using IBM Statistical Package for the Social Sciences (SPSS). The expected outcomes of this study would be beneficial to prove and validate factors that affects employee's happiness and the link to employee productivity thus, it might provide insights on companies to adopt ways in sustaining or increase the employees' happiness in the oil and gas industry
\end{abstract}

Keywords: Productivity, Happiness, Job Performance, Oil and Gas, Quantitative, United Arab Emirates

\section{INTRODUCTION}

Happiness, commonly defined as the internal state or feeling of satisfaction accompanied with pleasant emotions, moods and positive attitudes, is among the most widelyresearched topics in the field of psychology [1]. In the context of the workplace, research interest in exploring the factors that affects happiness. Study on employees' happiness has recently gained much attention due to its emphasis in organizational studies and the impact it has on overall employee performance [2]. This is primarily driven by the assumption that the amount of happiness experienced

Revised Manuscript Received on April 19, 2019.

Naser Yassin Al Hammadi, Faculty of Technology Management and Business, Universiti Tun Hussein Onn Malaysia, 86400 Parit Raja, Batu Pahat, Johor, Malaysia

Md Asrul Nasid Bin Masrom, Department of Construction Management, Faculty of Technology Management and Business, Universiti Tun Hussein Onn Malaysia, 86400 Parit Raja, Batu Pahat, Johor, Malaysia

Sulzakimin Mohamed, Department of Construction Management, Faculty of Technology Management and Business, Universiti Tun Hussein Onn Malaysia, 86400 Parit Raja, Batu Pahat, Johor, Malaysia. by workers plays a crucial role in their level of productivity and efficiency in the workplace [3]. Apparently, it is believed that the happiest workers are also the most productive while those workers who are unhappy with what they do tend not to pay full attention to the quality of their accomplishments and tasks .Being happy is of great importance to most people, and happiness has been found to be a highly valued goal in most societies [4]. Happiness leads success in all areas of life. Oftentimes it is happiness that increases our odds of success [5]. According to Fredickson (2005)[6], People who approach tasks with positivity have been found to be more productive, creative and resilient. Happy workers enjoy multiple advantages over their less happy peers, they obtain a job, they show superior performance and productivity, and they handle managerial jobs better. They are also less likely to show counterproductive workplace behavior and job burnout. [7] According to Chiumento (2007)[8], people who are happiest at work are $180 \%$ more energized, $180 \%$ happier with life, $155 \%$ happier in their job, $108 \%$ more engaged at work, and love their job $79 \%$ more. Also, Chiumento added that $50 \%$ of the happiest people at work are also more motivated than others. Their confidence is $40 \%$ higher, and they reach their goals 30\% more often. Moreover, [9] proves that happiness raises nearly every business and educational outcome: increasing sales by $37 \%$, productivity by $31 \%$, and accuracy on tasks by $19 \%$.Oil and gas industry are important, one of its importance is for the number of jobs they provide. Tens of thousands of people work in the oil and gas industry (world-petroleum.org). The backbone of the United Arab Emirates economy is production and export of oil and gas (dubaifreezone.ae). UAE is seventh in holding both oil and natural gas reserves in the world. Abu Dhabi endowed the largest oil deposit in the UAE (about 90\%). However, in recent years, oil and gas companies in UAE have changed especially on how they handle the decline of global oil price. Trefis et.al, (2018) [10]said that "weak oil prices would result in lower price realization for these companies, causing their revenues as well as earnings to drop significantly". Falling of the oil prices adversely affected the upstream of oil and gas in the Emirates region which caused many projects to be put on hold [11]. This resulted to cutting down benefits and other expenses that leads to employee's instability, insecurity and uncertainty that may have created unhappiness in the organization.Happiness can be construed as the difference between experienced positive affect and experienced negative affect [12]. Thus, maximizing 
happiness may be achieved by either maximizing positive experiences or minimizing negative experiences [13]. It is normal that employees feel dissatisfied with their jobs at one point or another [14]. According to Gallup Study, [15] stated that, when employees are unhappy, they are not as engaged and are not as productive, and they do not care as much about the success of the business. Gallup study shows that in Washington D.C, only $13 \%$ of employees worldwide are engaged at work. Gallup's study also shows that bulk of employees worldwide $63 \%$ are "not engaged," meaning they lack motivation and are less likely to invest discretionary effort in organizational goals or outcomes. And 24\% are "actively disengaged," indicating they are unhappy and unproductive at work and liable to spread negativity to coworkers.Miles, et.al. (2013)[16] claim that a negative mood moves people into an entirely different way of thinking and acting. Negative people concentrate on what is wrong and attempt to correct it (psychologytoday.com). Unhappy people tend to pull away from social situations wanting little contact with others, especially co-workers or customers that may be the source of their unhappiness. Unhappy people are less willing to contribute ideas in a discussion or offer assistance or idea exchanges with others [17][18]. Moreover, a very destructive consequence of unhappiness is work withdrawal. Work withdrawal is a family of behaviors that is defined as employees' attempts to remove themselves, either temporarily or permanently, from quotidian work tasks [19].

According to a survey, $50 \%$ of total waking hours during any given working day spend at work. Since the majority of people spend much of their lives at work, it is critically important to gain a solid understanding of the role that employment and the workplace play in shaping happiness for individuals and communities around the world. Happiness at the workplace is important to both individuals and organizations [20], although the research on employee happiness in organizations is limited [21]. This study will give a substantial knowledge and ideas on factors that affect employees' happiness. This will focus largely on employees' personal features and organizational characteristics in shaping their happiness. Employees happiness became a widely concern to organizations not only to oil and gas industries. Having a clear understanding and identify the factors that affects the happiness of employees to be able to appropriately apply the knowledge to increase employee's happiness and moreover to increase their productivity. Based on the background of the research, the following research questions are formed. There are mainly three objectives of this research. First objective is to identify the internal factors affecting the happiness of employees, the second is to identify the external factors affecting the happiness of employees and the third objective is to investigate the relationship between the affecting factors of happiness and employee's productivity. These three objectives will answer the two main research questions i.e What are the factors that affects happiness of oil and gas employees and How these factors related to their productivity.

\section{LITERATURE REVIEW}

Several scholars have defined happiness in a variety of ways. The Greek word that usually gets translated as "happiness" is Eudaimonia which refers to a state of having a good indwelling spirit or being in a contented state of being healthy, happy and prosperous(positivepsychologyprogram.com). For Aristotle, however, happiness is a final end or goal that encompasses the totality of one's life. It is not something that can be gained or lost in a few hours, like pleasurable sensations. It is more like the ultimate value of your life as lived up to this moment, measuring how well you have lived up to your full potential as a human being [22]. According to Martin Seligman, the founder of positive psychology, happiness in the present is a combination of satisfaction about the past and optimism about the future. He embraces both positive feelings and positive activities, explaining that sometimes happiness does refer to activities without anything felt, e.g. absorption or engagement [23]. Satisfaction is one term which is frequently used interchangeably with happiness. The Oxford dictionary defines satisfaction as "the feeling of pleasure that arises when you have the things you want or need or when the things you want to happen, happen" [24][25]. It is further defined as the state of pleasurable content of mind, which results from success or the attainment of what is considered good. Happiness is a complex and open to subjective and objective perspectives. Meaning of happiness can be based on experiencing positive emotions and the other is based on how righteous living of one's life. Table 1 will show a summary of the definition of happiness.

The focus of the study is happiness of employees in the workplace. Happiness in the workplace has not been studied extensively until relatively recently. Even though several researches have been made about happiness at workplace, it is not a term that has been extensively used in research on employee experiences in organizations. It is often used interchangeably with the terms quality of life [26], subjective well-being [27], life satisfaction, peak experiences, and important in maintaining health [28]. According to Boehm and Lyubomirsky (2010)[29], happiness is essential in the workplace as it is associated with positive feelings and emotions that bring about good impact in the way a person performs his/her job. Such emotions include satisfaction, joy, contentment, interest and enthusiasm, all of which are essential elements that are necessary in maximizing the effectiveness and productivity of an employee within the workplace. Employees' job satisfaction has an impact on organizational performance [30]. If they are satisfied with work, their productivity would be increased [31]. Happy people are more creative, take fewer day off, less likely to leave their work and add value to employers and bring success in competitive work environment [32].Different study shows positive and negative effects of happiness (unhappiness). Table 2 presents a summary of the different concepts of happiness in the workplace: 
Table 1 Summary: Concept of Happiness

\section{DEFINTION OF HAPPINESS}

- $\quad$ the totality of one's life (Aristotle)

- $\quad$ Positive feelings (Seligman, 2002)

- Positive moods (Amabile, Barsade, Muellerand Staw,

2005)

- $\quad$ Satisfaction (Seligman, 2002)

- $\quad$ Infrequent negative affect (Myers and Diner, 1995)

- $\quad$ Pleasurable (dictionary.com, 2009)

- $\quad$ Motivation (Santoso and Kulathunga, 2016)

- Financial well being (Gerrans, Speelmanand Campitelli

2013)

- $\quad$ Positive activities (Seligman, 2002)

- $\quad$ Creativity (Amabile, Barsade, Muellerand Staw, 2005; Fritz and Sonnentag, 2009)

- $\quad$ Comfortable (Hawker and Waite, 2007)

- $\quad$ Health (Pressman and Cohen,2005)

- $\quad$ Enjoyments (Bekhet et al., 2008)

- $\quad$ Success (Lyubomirsky and King,2005)

- $\quad$ Work Engagement (Fisher,2010)

- $\quad$ Better Performance (Santoso and Kulathunga, 2016)

- $\quad$ Generates Productivity (Mateu 2015)

Table 2 Summary: Happiness of Employees in Workplace

CONCEPTS OF HAPPINESS IN THE WORKPLACE

\begin{tabular}{|c|c|c|}
\hline $\begin{array}{c}\text { Common } \\
\text { Themes }\end{array}$ & Concepts & Authors \\
\hline \begin{tabular}{lr}
\multicolumn{1}{c}{ Happiness } \\
equated & with \\
satisfaction & and \\
well-being &
\end{tabular} & $\begin{array}{l}\text { Used } \\
\text { interchangeably } \\
\text { with terms such as } \\
\text { job satisfaction, } \\
\text { quality of life and } \\
\text { subjective well- } \\
\text { being }\end{array}$ & $\begin{array}{l}\text { Veenhoven } \\
(2005) ; \quad \text { Levett } \\
(2010)\end{array}$ \\
\hline \begin{tabular}{l}
\multicolumn{3}{c}{ Happiness being } \\
linked to positive \\
feelings \\
emotions
\end{tabular} & $\begin{array}{l}\text { Associated with } \\
\text { positive feelings } \\
\text { and emotions (i.e., } \\
\text { satisfaction, joy, } \\
\text { contentment, } \\
\text { interest and } \\
\text { enthusiasm) that } \\
\text { bring about good } \\
\text { impact in the way a } \\
\text { person performs } \\
\text { his/her job. }\end{array}$ & \begin{tabular}{l}
\multicolumn{1}{c}{ Boehm and } \\
Lyubomirsky \\
$(2010)$
\end{tabular} \\
\hline \begin{tabular}{l}
\multicolumn{1}{c}{ Happiness } \\
associated with \\
organizational \\
performance
\end{tabular} & $\begin{array}{l}\text { Has an impact } \\
\text { on organizational } \\
\text { performance }\end{array}$ & $\begin{array}{l}\text { Dalal, Baysinger, } \\
\text { Brummeland } \\
\text { Lebreton (2012) }\end{array}$ \\
\hline $\begin{array}{l}\text { Happiness } \\
\text { linked } \\
\text { productivity }\end{array}$ & $\begin{array}{l}\text { Satisfaction with } \\
\text { work is equal to } \\
\text { increased } \\
\text { productivity }\end{array}$ & $\begin{array}{l}\text { Barmby, } \\
\text { Brysonand Eberth } \\
(2012)\end{array}$ \\
\hline $\begin{array}{l}\text { Happiness } \\
\text { linked } \\
\text { productivity }\end{array}$ & $\begin{array}{l}\text { Produces } \\
\text { individuals who are } \\
\text { creative, take fewer } \\
\text { days off, less likely } \\
\text { to leave their work } \\
\text { and add value to } \\
\text { employers while } \\
\text { bringing success in } \\
\text { competitive work } \\
\text { environment }\end{array}$ & $\begin{array}{l}\text { Pryce-Jones and } \\
\text { Scott }(2009)\end{array}$ \\
\hline Happiness & Happy & Quick and Quick \\
\hline
\end{tabular}

\begin{tabular}{|c|c|c|c|}
\hline $\begin{array}{l}\text { linked } \\
\text { productivity }\end{array}$ & to & $\begin{array}{l}\text { employees are } \\
\text { productive } \\
\text { employees }\end{array}$ & $\begin{array}{l}\text { (2004); Rego and } \\
\text { Cunha (2008) }\end{array}$ \\
\hline $\begin{array}{l}\text { Happiness } \\
\text { linked } \\
\text { productivity }\end{array}$ & to & $\begin{array}{l}\text { Unhappiness in } \\
\text { the workplace } \\
\text { reduces } \\
\text { productivity }\end{array}$ & $\begin{array}{l}\text { Fereidouni, } \\
\text { Najdiand Amiri } \\
(2013)\end{array}$ \\
\hline $\begin{array}{l}\text { Happiness } \\
\text { linked } \\
\text { productivity }\end{array}$ & to & $\begin{array}{l}\text { Employees who } \\
\text { are happiest in their } \\
\text { jobs tend to } \\
\text { demonstrate the } \\
\text { highest job } \\
\text { performance and } \\
\text { also, the highest } \\
\text { job retention as } \\
\text { compared to those } \\
\text { who are unhappy }\end{array}$ & $\begin{array}{c}\text { Wright and } \\
\text { Cropanzano (2007) }\end{array}$ \\
\hline $\begin{array}{l}\text { Happiness } \\
\text { linked } \\
\text { productivity }\end{array}$ & to & $\begin{array}{l}\text { Employees tend } \\
\text { to become more } \\
\text { productive and } \\
\text { effective at work } \\
\text { when they are } \\
\text { happier. }\end{array}$ & $\begin{array}{l}\text { Zelenski, } \\
\text { Murphyand Jenkins } \\
(2008)\end{array}$ \\
\hline $\begin{array}{l}\text { Happiness } \\
\text { linked } \\
\text { productivity }\end{array}$ & to & \begin{tabular}{l}
\multicolumn{1}{c}{ unhappiness } \\
related \\
performance and \\
productivity losses
\end{tabular} & $\begin{array}{l}\text { Abrahamsson, } \\
\text { et.al, } 2017\end{array}$ \\
\hline
\end{tabular}

Happiness is one interesting description that is used by many workers in the UAE oil and gas industry. Based on a study conducted in $2014,44 \%$ of the employees working for oil and gas companies in the UAE stated that they are content and satisfied with the salary packages they receive from their employers and $56 \%$ of them agreed that the best compensation packages in the entire UAE are in the oil and gas industry (Trade Arabia News Service, 2014). However, in recent years, the oil and gas industries in the UAE experienced economic challenges brought about by changes happening in the world market. According to Rubeis (2015)[11], the consistent falling of the oil prices adversely affected the upstream of oil and gas in the Emirates region which caused many projects to be put on hold across different parts of the world. In fact, an estimated $\$ 620$ billion worth of projects in the industry have been canceled or deferred as a consequence of this downturn and companies shifted their focus towards short-cycle projects instead of complex long-term projects [33]. In addition, on top of the volatile prices for oil and gas are the rising globa demand and the increasingly strict environmental regulations which continuously hinder the growth and stability of the oil and gas sector in the UAE. As a consequence of all these, different companies not only oil and gas industry poses a great challenge towards happiness. This is because as many as 3,000 employees were recently laid off in two key cities, Dubai and Abu Dhabi, as oil and gas companies are finding ways to cut down operational costs . It was also reported that many oil and gas companies within the sector have decreased efforts in hiring more staff and some have even frozen their plans for recruitment as 
they prioritize the continued survival of their companies instead of recruiting and retaining people [34]. Companies in the oil and gas industry in Abu Dhabi have also recently implemented cost-cutting measures which adversely affected their employees. In fact, there have been cases wherein high-paying expatriates were sent home and were replaced with lower-paid employees. Also, the employees' benefits and salary packages have also been cut down forcing many expats to leave the Emirates region to find more promising job opportunities in other countries. Indeed, given the economic challenges and the instability of the oil and gas sector in the UAE, the level of happiness and satisfaction of these employees was negatively affected. Table 3 shows the summary of the literatures which discuss happiness in the context of the UAE oil and gas industry:

Table 3 Summary:

Happiness in the UAE Oil and Gas Industry

SUMMARY OF LITERATURES:
HAPPINESS IN THE UAE OIL AND GAS
INDUSTRY

- A large number of employees in the UAE oil and gas companies are content and satisfied with their salary packages and claim that they have the best compensation packages (Trade Arabia News Service, 2014).

- In recent years, the oil and gas industries in the UAE experienced economic challenges (i.e., instability in oil and gas prices, billions worth of projects deferred, etc.) ( Rubeis, 2015); Deloitte, 2017).

- As a consequence of the economic challenges in the UAE oil and gas industry, thousands of employees were laid off as oil and gas companies seek to cut down operational costs (Latif, 2017).

- Decreased efforts in hiring staff and frozen recruitment plans have been experienced within the UAE oil and gas industry (Maceda, 2015).

- High-paying expatriates were sent home and were replaced with lower-paid employees and employees' benefits and salary packages have also been cut down (Kerr, 2017).

- Consequently, the level of happiness and satisfaction of employees have been adversely affected.

\section{THEORITICAL FRAMEWORK}

According to Mathur and Gupta (2012)[35], A large number of factors join hands together to determine a peculiar pattern of employee behavior in every organization, and it is governed by two factors namely internal and external. There are many factors affecting the level of employee happiness at work. The following literature review were identified to have influence the happiness of employees in the workplace.

\section{External Factors Affecting the Happiness Of Employees}

External or environmental factors are determinant within the organization that influence employee's happiness. The following literatures discusses that believed to impact employees' external factors of happiness.

Pay Structure
Most individuals choose to spend the majority of their adult lives in paid employment. This is the main reason for most of the individual why they tend to have work in the first place. As Jurgensen (1978)[36] said that the reasons individuals so devote themselves to work are varied, however, when individuals are asked why they work, money is one of the most commonly-cited reasons. According to Diener and Seligman (2004)[12], "Dozens of cross-sectional studies reveal that there is a positive correlation between individuals' incomes and their reports of well-being". A study of income and happiness by Caporale, et.al (2009)[37] confirms that there is a strong relationship between a person's income and life satisfaction. This is because people who have higher income have more opportunities to buy desired goods and services [38]. There are reasons to expect a positive or a negative relationship between pay level and job satisfaction. Most models of pay satisfaction stipulate a positive relationship between pay level and pay satisfaction, and pay satisfaction is one of the core components of overall job satisfaction [39].

Some research has revealed that pay level is negatively associated with turnover which one of the effects of employee's unhappiness. A study conducted revealed that there is a negative correlation between pay and turnover intention. [40] on his research claimed that, compensation and benefit were one of the major reasons for employees' happiness and unhappiness. Low level pay has made a significant impact on employees' happiness and performance.

\section{Working Hours}

Working hours and working time arrangements are key elements of working conditions and determine the possibilities for employees to balance work with their other life spheres. This development has led to an increasing literature that suggests the impact that the changed work time patterns might have on the satisfaction, happiness and well-being of workers and their families [41].

Researches shows that there are many advantages for employers and employees exist when there is flexibility in working hours. Some of Heathfield explain the advantages such as flexibility to meet family needs, personal obligations, and life responsibilities, reduces employee burnout due to overload and increased feeling of personal control over schedule and work environment. Also, in other research, even though people who gain higher income seem to be happier people, their happiness level is affected by working hours [42]. People may be unsatisfied with their jobs if they have long working hours. Overall, persons who are satisfied with the length of their working hours tend to be more satisfied with their jobs in.

\section{Geographical Location}

A person does not stay in an organization only for salary, but he/she may stay for many other reasons such as nature of work, good working relation, better working environment and preferable job location. Some organization implemented programs such as working from home to accommodate 
preferable job location to employees. According a research, there are several perceived benefits to both employers and employees when working from suitable job location, increase productivity, reduction in sick days, cost savings and job satisfaction. Also, research found out that happy employees bring their happiness from the office to their home; likewise, they also transfer their happiness from their home to the office [43].

\section{Training Needs}

Employee stays longer in the employment when they undergo training and development to improve their competency and also increase job satisfaction. Jones (2004)[44] suggest that, if workers are mismatched in terms of skill and education requirements, this may lower job satisfaction.Companies which are providing the training and development programs for their employees are achieving high level of employee satisfaction. Shelton (2001)[45] studied the effects of employee development programs on job satisfaction and employee's retention aiming on business success. He found that training and development increase employee satisfaction. Sahinidis et al. (2007)[46] studied the effectiveness and job satisfaction, motivation and commitment in five Greek companies and found that there is a significant correlation between the employee perceived training effectiveness and their commitment, job satisfaction and motivation. David and Stephen said that training and leading factor that contributes to employee overall job satisfaction.

\section{Rewards and Promotion System}

Rewards refer to as pay and promotion which is considered most related to job satisfaction when employees feels that they are rewarding fairly, their experience towards satisfaction is increased. Promotion arrangements can reward individual behavior by providing security, status, and skill development. They can also benefit the organization by helping it reach its productivity and performance goals. Also, according to Robbins, Odendaal, \& Roodt, (2003)[47]that there are different factors of rewards and promotion such as work rewards, pay, relationship with coworkers and job security which has substantial influence on job satisfaction. Moreover, It was found that there is also positive relationship between job satisfaction and rewards exists and rewards are considered key factor in determining job satisfaction of employee.

\section{Performance Evaluation}

Many of the employees expect to have a fair performance evaluation from their superior and knowing that the employee is evaluated fairly increase their happiness. According to Herzberg and Mausner (1959)[48] that, selfassessment and the professional autonomy will be two of the most important factors that firms will have to develop if they want to promote happiness among their workers. Roberts has highlighted the importance of employee participation in the appraisal process. In his article, he has summarized the conceptual foundation of participation including its intrinsic motivational value. He claims that if employees are confident in the fairness of the appraisal relationship between perceived employee training development, also defined as career development is another

process, they are more likely to accept performance ratings, even adverse ones, if they perceive fair decision-making process. In any case, if the employees perceive the process as unfair and not systematic and thorough, it is unlikely that they will accept the outcome of the appraisal exercise. He added, unless the employees are well informed about their performance and also their strong and weak points, it is very difficult for them to improve their level of performance and this may cause unhappiness to employees.

\section{Internal Factors Affecting the Happiness Of Employees}

Internal factors according to Schimack are factors within an individual that cause him or her to have a particular level of life satisfaction independent of an individual's environment. For example, two individuals with the same income may have different levels of income satisfaction. The following literatures believed to be factors that affects internal happiness of employees.

\section{Job Satisfaction}

At this point, employee's happiness is affected by different factors like salary, location and other more factors that are different to explain like job satisfaction. Aziri said that, there is still no general agreement regarding what job satisfaction is. As a matter of fact, different authors have different interpretation on job satisfaction. George try to explain job satisfaction as the collection of feeling and beliefs that people have about their current job. It is more like an attitude, an internal state . Job satisfaction can be considered as one of the main factors that affects employee's happiness and often it is interchangeably use as employee happiness itself. Kaliski implies that job satisfaction is enthusiasm and happiness with one's work.

\section{Career Advancement}

Career development is an incentive tool. It also a good way of rewarding employees that cause them to become happier in workplace. Lazear \& Rosen stated that career development is a way of rewarding the employees for meeting the organizational goals thus it serves as a mean of synchronizing organizational goals with personal goals. Pergamit and Veum established that greater the chances of career development possibilities, higher will be the job happiness of employees. Apart from job happiness, the employee happiness is determined by happiness with promotion. When employees perceive that there are golden chances for career development possibilities, they feel satisfied for the respective place in the organization.On the other hand, the lack of career development cause unhappiness to employees. According to Belt lack of career development one of the most frequently cited causes of employee turnover in employees. In other words, availability of career development possibilities creates an environment of employee's happiness and cause them to stay in the organization.

\section{Role Alignment}

Role alignment generally refers to employee alignment in 
which employee devote time and effort to do things that in line with organizational goal and value. May define it as employees developing a sense of meaning and purpose in their work role and identifying themselves with their work. When employee starts doing things that it is not aligned with his/her role, dissatisfaction and unhappiness could increase. Bakker, suggest that this minimizes the employee efficiency and productivity. For example, employees whose values are aligned with those of the organization would be highly motivated toward the mission of the organization and be passionate in their work role because of their perceptions that they are making a difference. Role alignment will play a crucial role on employees' happiness and also it would be beneficial to the organization. This is because organizational goals are explicitly delineated to employees that assimilate them into the role they play in accomplishing the organization's most critical goals.

\section{Relationship with Superiors}

An organization is made up of individuals who each have their own different thoughts, feelings, and interests. Within the organization, interactions between these individuals are inevitable. It has been seen that perceptions of a lack of fairness in management practices and unhappiness with supervision lead to high level of employee's unhappiness. Too little managerial support is related to lower job happiness as well as lower performance. Workers at every level form impression regarding whether they are valued and respected, from important cues that emanate from their environment, especially those that come from the leaders that they report into. Having a good relationship with the leader of the organization causes employees to become happier. A study of Andrew of happiness at the workplace regarding servant-leadership behaviors were found to be highly correlated.

\section{Working Environment}

Employees working conditions really play an important role in company's ability to attract retain and motivate good employees, hence cause of employee's happiness. Schwartz adds that those working conditions, which include physical and psychological factors surrounding a job, vary in importance as a motivator and the absence of such motivating factors. In addition, working conditions that contribute to the satisfaction of workers lead to higher motivation and commitment.On the other hand, the environment in which people work has a tremendous effect on their level of happiness for themselves and for the work they are doing. Physically demanding and tiring and does not promote something valued by the worker. According to Noel , most employees react negatively to extreme physical working environment. Smith and de Cronje found out that the employee becomes discontented and may eventually leave the job if the working environment is not safe and requires are more demanding physical effort. Providing a safe and suitable working condition promotes happiness. Several studies suggest that, HR managers need to design and manage a workplace to enhance employee happiness.

\section{Meaningfulness of Work}

Meaning appears when a person finds what he/she was looking for in his or her life, something that makes him/her feel significant and purposeful. Meaningfulness of life is often divided into two parts, such as meaningfulness of work plus psychological meaningfulness. According to Vuori, San and Kira, "work meaningfulness refers to a subjective state which results from a high level of positivity in the entities that one associates with his or her work.Similarly, as Carvalho, many researchers have agreed that meaningful work is one of the factors that make life meaningful and may result to employee's happiness. According to Herzberg.Each worker needs to feel his work is part of a whole that will influence the others. Also, it is an internal driver of human beings to act accordingly. In other words, meaningful work is not only a part of a human perception of his/her life as a whole, but particularly actions he/she performs to make his life and life of others even more meaningful and subsequently being happy.

\section{Internal Factors Affecting the Happiness Of Employees}

\section{Quality of Work}

Quality of work also refers to job quality is something on how an employee do his/her job. Quality of work constitutes the activity of work itself and the conditions under which it takes place. Having a productive employee is nothing if their quality of work is low. This is due to many factors such as lack of training, not fit for the job and also lack of resources. Barling define quality of work as high-quality work provides the employee with the means (through extensive training) and the opportunity to do great work Overall, a good measure of performance of an employee requires not only the quantity of the job done but also it is a matter of how high quality of work it is.

\section{Working Relationship}

Working relationship of employees is vital in order to increase productivity of the organization. Employees who are working together can be considered as a team and according to Wiese and Shuffler, suggest that teams are essential in order to handle the complex problems faced by the contemporary organization. So good and healthy working relationship among employees should be maintain. According to Lee and Park, friendships that develop in the workplace may be called blended friendships which can have a positive impact on an employee's work performance $\&$ productivity. Good working relationship makes a good teamwork performance that is required in an organization especially those organization that have complicated job.

\section{Time Management}

Time management is the act or process of planning and exercising conscious control over the amount of time spent on specific activities, especially to increase effectiveness, 
efficiency or productivity. It is a good way to measure performance of employees. Time management may be aided by a range of skills, tools, and techniques used to manage time when accomplishing specific tasks, projects and goals complying with a due date. Abduljabbr et, al (2012)[49]concluded that time management is needed for any organization to succeed and found out that there is a positive connection between time management and job performance. This study focuses on identifying the factors affecting the happiness of employees in relations to employee's productivity. Below is the schematic diagram which shows the variables included in this study.

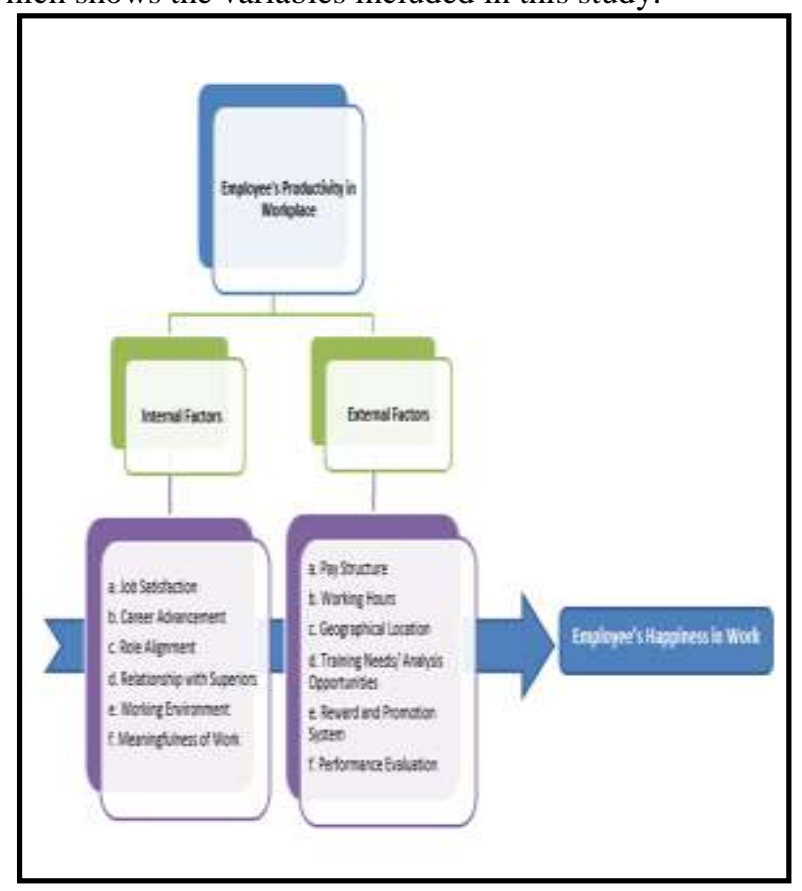

Figure 1 Conceptual Framework

Figure 1 illustrates the relationship among variables. It represents the conceptual framework for this study. It illustrates the factors affecting employee's happiness. These factors were categorized into two; internal and external factors. The dependent variable (DV) of this study or the employee's productivity is influenced or is dependent on these factors which make up the independent variables (IV) of this study. These factors are basically why employees are unhappy. Intrinsic motivation was first studied through animal behavior, and then transferred into studies of human behavior [50]. A person gains understanding of skills through acting on a previous interest. It is also important to point out that not every person is intrinsically motivated for every single task and does need some extrinsic motivation as well. Intrinsically motivated behaviors in turn feed the psychological needs of a person, such as competency or self-worth. On the other hand, extrinsic motivation has a separate reward other than feelings from within.

\section{RESEARCH METHODOLOGY}

This research study, which aims to investigate factors affecting happiness of employees in the oil and gas industry in the UAE, applied a quantitative research study in order to critically evaluate whether the existing workers in the said sector are happy in their present jobs. In order to obtain reliable findings, the participants of the study were selected oil and gas companies in Abu Dhabi, UAE, the research population for this study were mainly existing workers in the oil and gas in the chosen company, ADNOC (Abu Dhabi National Oil Company) which has a population of 25,000 employees. This included employees from the bottom and middle level of the organization such as the oil rig workers, engineers, and other field and non-field workers as these employees were more greatly represent the oil and gas and also directly affected and susceptible to change in the organization which means any change in the company affected their happiness in positive or negative way. Comprehensive research processes were conducted to achieve the aims of this quantitative study. The research process began with the collation of various literature reviews and ideas obtained from scholarly sources and references. This followed by the identification of the research problems and research objectives and a consultation and approval with the academia. This followed by the development of the conceptual framework, which depicted initial assumptions and beliefs about the research topic, specifically the attributes of employees' happiness. After the first stage (literature review) of the research process, the second stage began which was the data collection and analysis. This stage included discussions on the methodology approach to be applied in the study including the questionnaire development that is mainly based on the literature review and the survey, which identified the attributes of employees' happiness. The third stage, which presents the results of the study immediately, follows the second stage. This covered the conclusions, recommendations and further studies. (see figure 2).

Figure 2. Research Methodology

\section{V.FINDINGS}

The demography of the respondents showed that majority of respondents' age came from bracket above 36 , to be followed by age bracket 26 to 35 from all the oil and gas employees. The least group came from set 18 to 25 age brackets. According to SHRM report (2016), $27 \%$ of the employees in mining, quarrying and oil and gas extraction have the age of over 55, this constitute that this kind of industries requires more experienced person than less experienced employees. It also shows that majority of respondents' status were male with $88 \%$. Women are underrepresented in the oil and gas industry in general. Lee and Inajima reported that women accounted for only $22 \%$ of the workforce in oil and gas, one of the smallest ratios among major industries. Construction industries are lower with $11 \%$. This is primarily driven that oil and gas industries around the world requires male workforce especially on-site jobs that requires a more physical effort. Though the share of female workers in office-based roles has increased, it is still male counterpart is needed in technical and field roles outside of the office. Majority of the respondents are married in status which has $67 \%$ or 252 out of 379 respondents. Workforce Survey also shows that $69 \%$ of the hired employees are married and $16 \%$ are single, other $15 \%$ have more complicated relationships. Considering also the age that oil and gas industries are hiring, the age that usually get hired are the one who have already established a 
family. It also reveals that majority of respondents' highest educational attainment have a college degree with $71 \%$, to be followed by with Master's Degree Holder, and the last have With Master's Degree Holder. This is the basic requirement to have a job in a certain company. Employers usually have their own age requirements for workers. Although many applicants with tertiary education diplomas apply in oil and gas firms, their skill levels do not meet industry requirements. Only $6-10 \%$ of the applicants are effectively recruited and deployed for an entry-level job (Ortiz and Capistrano, 2009). Majority of respondents came from Indian (25.6\%), Arabic (22\%) and Pakistan (21.4\%) nationality. In terms of ethnic breakdown, the majority of expat workers are from subcontinent (Bangladesh, Indian, Pakistan, Nepal, Sri Lankan etc.). Next group would be in Arab Nationals and expats from Jordan, Egypt, and other GCC countries. In past years, most of the workers in the UAE are expatriates but in the early 1990s, the government in the UAE introduced a workforce nationalization policy, called Emiratization, to create opportunities for national workers in public and private sector organizations and reduce the reliance on expatriate workers .The length of working experience profiles of the respondents it reveals that majority of the respondents are working from 6 to 15 years. Employees in oil and gas industries are constantly moving to a better company that could provide them better condition because of their job experience is exceptional. Oil and gas companies started programs that could make employees stay. They are making all-out efforts to provide long-term growth opportunities to their employees. This could be in a form of many trainings in communication, technical and life skills that

employees need to become successful and prolong the years of working experience.

Table 5 Pay structure

\begin{tabular}{|l|l|l|}
\hline Items & Mean & $\begin{array}{l}\text { Verbal } \\
\text { Interpret } \\
\text { ation }\end{array}$ \\
\hline $\begin{array}{l}\text { 1. I am satisfied with my } \\
\text { current salary. }\end{array}$ & $\begin{array}{l}\text { Fairly } \\
\text { Agree }\end{array}$ \\
\hline $\begin{array}{l}\text { 2. I am satisfied with the } \\
\text { allowances provided by the } \\
\text { organization }\end{array}$ & $\begin{array}{l}\text { Fairly } \\
\text { Agree }\end{array}$ \\
\hline $\begin{array}{l}\text { 3. The salary given motivates } \\
\text { me to perform my job well. }\end{array}$ & 3.87 & Agree \\
\hline $\begin{array}{l}\text { 4. Incentives influence my } \\
\text { performance/productivity at } \\
\text { work }\end{array}$ & 3.17 & $\begin{array}{l}\text { Fairly } \\
\text { Agree }\end{array}$ \\
\hline $\begin{array}{l}\text { 5. I am satisfied with the } \\
\text { benefits given to me by the } \\
\text { company like medical and } \\
\text { insurance. }\end{array}$ & & Agree \\
\hline $\begin{array}{l}\text { Total } \\
\text { and }\end{array}$ & $\begin{array}{l}\text { Fairly } \\
\text { Agree }\end{array}$ \\
\hline
\end{tabular}

Based on pay structure factors with mean of 3.48 , it reveals that this factor has certainly or fairly positively affected the employee's happiness (fairly agreeing) on the satisfaction of their current salary and incentives/benefits they received and one of the reasons why some employees not satisfied in their salary. According to the study of Miller

, sixty percent of employees rated compensation/pay "very important," and 36 percent rated it "important," making it the top contributor to overall employee job satisfaction - up from the No. 3 position year 2012 in Job Satisfaction and Engagement: The Road to Economic Recovery, when "job security" and "opportunities to use skills/abilities" were the leading drivers of satisfaction.

Table 5 Working Hours

\begin{tabular}{|c|c|c|}
\hline Items & Mean & $\begin{array}{c}\text { Verbal } \\
\text { Interpretation }\end{array}$ \\
\hline $\begin{array}{l}\text { 1. There is a flexible } \\
\text { working hour policy in my } \\
\text { workplace }\end{array}$ & 2.84 & Fairly Agree \\
\hline $\begin{array}{l}\text { 2. The use of time as } \\
\text { flexible employees are often } \\
\text { more disciplined in their } \\
\text { time management. }\end{array}$ & 3.27 & Fairly Agree \\
\hline $\begin{array}{l}3 . \quad \text { It is easy for me to } \\
\text { adopt a flexible working } \\
\text { arrangement because of the } \\
\text { support from my supervisor }\end{array}$ & 2.96 & Fairly Agree \\
\hline $\begin{array}{l}4 . \text { The company paid me, } \\
\text { once I render overtime } \\
\text { work. }\end{array}$ & 3.86 & Agree \\
\hline $\begin{array}{l}5 . \quad \text { I am compensated } \\
\text { when I work during } \\
\text { holidays, company event } \\
\text { and rest days. }\end{array}$ & 4.64 & Agree \\
\hline $\begin{array}{l}\text { Total } \\
\text { Interms of }\end{array}$ & $\mathbf{3 . 5 1}$ & Agree \\
\hline
\end{tabular}

In terms of working hour's factor that has a mean of 3.51, they also factor have positively affected the employee's happiness (agreeing) on the working hour's policy in their workplace as one reason of employee's happiness. According to Possenriede and Plantenga they analyze whether flexibility in the work schedule (flexi-time), location and duration improves the work/leisure balance and increases employee's overall job satisfaction. They use panel data on Dutch households with self-reported measures of job satisfaction. In the sample, $39 \%$ of the employees report freedom to determine the start and end times of their work, and $17 \%$ work at home at least once a week. The analysis finds that a flexible work schedule is positively associated with both working-time fit and job satisfaction.

Table 6 Geographical Location

\begin{tabular}{|c|c|c|}
\hline Items & Mean & $\begin{array}{c}\text { Verbal } \\
\text { Interpretation }\end{array}$ \\
\hline $\begin{array}{c}\text { 1. My place of work is } \\
\text { accessible to my house. }\end{array}$ & 2.33 & Disagree \\
\hline $\begin{array}{c}\text { 2. My place of work is } \\
\text { accessible to malls. }\end{array}$ & 3.64 & Agree \\
\hline $\begin{array}{l}\text { 3. My place of work is } \\
\text { accessible to hospitals. }\end{array}$ & 4.20 & Agree \\
\hline $\begin{array}{c}\text { 4. The company has } \\
\text { branches or offices to } \\
\text { choose from If will be } \\
\text { relocated in other places }\end{array}$ & 4.87 & Agree \\
\hline
\end{tabular}




\begin{tabular}{|l|l|l|}
\hline $\begin{array}{l}\text { 5. The location of the } \\
\text { company is perfect for the } \\
\text { business district office in } \\
\text { the area. }\end{array}$ & 3.29 & Fairly Agree \\
\hline Total & $\mathbf{3 . 6 7}$ & Agree \\
\hline
\end{tabular}

In Geographical location a factor that has a mean of 3.67, this factor has certainly or positively affected the employee's happiness (agreeing). This explains that places where oil and gas industry are located have the necessary needs to grow family and have work-life balance. Having a work location that caters the basic needs improves employee's happiness and productivity. Possenriede and Plantenga said that location flexibility provides employees with more control over their working life, leads to a better match between paid work and other activities, decreases the amount of stress experienced by employees, and signals to workers that their employer cares about their well-being and their responsibilities outside work.

In training opportunities with mean of 3.62 have certainly or positively affected the employee's happiness (agree). Skills trainings and development is a must for oil and gas industries, this is due to technology nowadays are changing fast and employees need constant training to stay competent, be able to do the work and this boost the happiness of employees.

\section{Table 7 Training Needs/ Analysis Opportunities}

\begin{tabular}{|c|c|c|}
\hline Items & Mean & $\begin{array}{c}\text { Verbal } \\
\text { Interpretation }\end{array}$ \\
\hline $\begin{array}{l}\text { 1. I get the training } \\
\text { and development I } \\
\text { needed in my job to } \\
\text { identify the } \\
\text { skills/knowledge gaps } \\
\text { within the business. }\end{array}$ & 3.26 & Fairly Agree \\
\hline $\begin{array}{l}\text { 2. I have a role in } \\
\text { supporting my work- } \\
\text { related training and } \\
\text { development needs. }\end{array}$ & 3.97 & Fairly Agree \\
\hline $\begin{array}{lcr}3 . & \text { My } & \text { team } \\
\text { supports my } & \text { work- } \\
\text { related training and } \\
\text { development. }\end{array}$ & 3.14 & Fairly Agree \\
\hline $\begin{array}{l}\text { 4. I am satisfied } \\
\text { with the training } \\
\text { opportunities available } \\
\text { in my work. }\end{array}$ & 3.61 & Fairly Agree \\
\hline $\begin{array}{l}\text { 5. My team helps } \\
\text { me meet my work- } \\
\text { related training needs. }\end{array}$ & 4.11 & Agree \\
\hline Total & 3.62 & Agree \\
\hline
\end{tabular}

Table 8 Reward and Promotion System

\begin{tabular}{|c|c|c|}
\hline Items Mean & $\begin{array}{c}\text { Verbal } \\
\text { Interpretation }\end{array}$ \\
\hline $\begin{array}{c}\text { My superior gives } \\
\text { recognition for significant } \\
\text { employee's achievement. }\end{array}$ & 3.26 & Fairly Agree \\
\hline $\begin{array}{l}2 . \quad \text { There are formal } \\
\text { recognition programs that } \\
\text { increase the motivational } \\
\text { value of the employees. }\end{array}$ & 2.57 & Fairly Agree \\
\hline $\begin{array}{l}\text { 3. The company looks at } \\
\text { the skills of the employees to } \\
\text { promote us in higher } \\
\text { position. }\end{array}$ & 2.51 & Fairly Agree \\
\hline $\begin{array}{c}\text { 4. There is a little chance } \\
\text { for promotion in my job. }\end{array}$ & 2.48 & Fairly Agree \\
\hline $\begin{array}{c}\text { 5. The job promotions in } \\
\text { my company are awarded } \\
\text { fairly and without bias. }\end{array}$ & 2.03 & Disagree \\
\hline \begin{tabular}{c} 
Total \\
\hline
\end{tabular} & $\mathbf{2 . 5 3}$ & Fairly Agree \\
\hline
\end{tabular}

This factors the rewards and a promotion system that has a mean of 2.53 , respondents have certainly or fairly positively affected the employee's happiness (fairly agree). Feeling appreciated for their time and efforts creates a bond between employees, management and their organization. Overall rewards and benefits were the third most important job satisfaction contributor, with $60 \%$ of employees rating it as very important.

Table 9: Performance Evaluation

\begin{tabular}{|c|c|c|}
\hline Items & $\begin{array}{c}\text { Mea } \\
\text { n }\end{array}$ & $\begin{array}{c}\text { Verbal } \\
\text { Interpretation }\end{array}$ \\
\hline $\begin{array}{l}\text { 1. I am able to meet the } \\
\text { company's expectations. }\end{array}$ & 3.15 & Fairly Agree \\
\hline $\begin{array}{l}\text { 2. I am able to maintain } \\
\text { schedule (complete on time } \\
\text { or early). }\end{array}$ & 3.07 & Fairly Agree \\
\hline $\begin{array}{l}\text { 3. I have a quality of } \\
\text { workmanship. }\end{array}$ & 2.89 & Fairly Agree \\
\hline $\begin{array}{l}\text { 4. I was clear from the } \\
\text { discussion that the purpose } \\
\text { was to help me do a better } \\
\text { job and develop my skills } \\
\text { and career. }\end{array}$ & 3.78 & Agree \\
\hline $\begin{array}{l}\text { 5. I am clear from my } \\
\text { performance reviews and } \\
\text { other discussions what my } \\
\text { supervisor expects of me. }\end{array}$ & 2.66 & Fairly Agree \\
\hline $\begin{array}{l}\text { TOTAL } \\
\text { In Performance evaluaton, it shows }\end{array}$ & $\mathbf{3 . 1 1}$ & $\begin{array}{c}\text { Fairly } \\
\text { Agree }\end{array}$ \\
\hline
\end{tabular}

In Performance evaluation, it shows that the employees are fairly agreeing on their company's performance evaluation to them with overall weighted mean of 3.11 . Performance evaluation is not only given to increase the productivity of an employee but also it also increases the happiness if the evaluation is done fairly and transparent. 
International Conference on Recents Advancements in Engineering and Technology (ICRAET-18) |15th and 16th March 2019|Siddhartha Institute of Technology \& Sciences, Telangana, India.

Awosusi said that unless the employees are well informed about their performance and also their strong and weak points, it is very difficult for them to improve their level of performance.

Table 10: Summary of External Factor

\begin{tabular}{|c|c|c|}
\hline Items & Mean & \begin{tabular}{l}
\multicolumn{1}{c}{ Verbal } \\
Interpretati \\
on
\end{tabular} \\
\hline 1. Pay Structure & 3.48 & $\begin{array}{l}\text { Fairly } \\
\text { Agree }\end{array}$ \\
\hline 2. Working Hours & 3.33 & $\begin{array}{l}\text { Fairly } \\
\text { Agree }\end{array}$ \\
\hline $\begin{array}{cc}3 . & \text { Geographical } \\
\text { Location } & \end{array}$ & 3.67 & Agree \\
\hline $\begin{array}{l}\text { 4. Training Needs/ } \\
\text { Analysis Opportunities }\end{array}$ & 3.62 & Agree \\
\hline $\begin{array}{ccc}5 . & \text { Reward } & \text { and } \\
\text { Promotion } & \text { System } & \\
\end{array}$ & 2.53 & $\begin{array}{l}\text { Fairly } \\
\text { Agree }\end{array}$ \\
\hline $\begin{array}{cc}6 . & \text { Performance } \\
\text { Evaluation } & \\
\end{array}$ & 3.11 & $\begin{array}{l}\text { Fairly } \\
\text { Agree }\end{array}$ \\
\hline Total & 3.29 & $\begin{array}{l}\text { Fairly } \\
\text { Agree }\end{array}$ \\
\hline
\end{tabular}

Overall mean score of external factors of happiness is 3.29 which means employees in oil and gas industry is fairly positively agreeing to the external factors that affects their happiness. This shows that company in oil and gas industry provide enough external motivation factors that could increase employee's happiness.

Table 11: Job Satisfaction

\begin{tabular}{|c|c|c|}
\hline Items & Mean & $\begin{array}{c}\text { Verbal } \\
\text { Interpretation }\end{array}$ \\
\hline $\begin{array}{l}\text { 1. I have the } \\
\text { opportunity of growth } \\
\text { factor of the employee } \\
\text { is satisfactory. }\end{array}$ & 3.23 & Fairly Agree \\
\hline $\begin{array}{l}\text { 2. I am satisfied with } \\
\text { the performance } \\
\text { appraisal system of } \\
\text { your company at work } \\
\text { place. }\end{array}$ & 3.64 & Agree \\
\hline $\begin{array}{l}\text { 3. I am satisfied with } \\
\text { the motivational factor } \\
\text { like achievement } \\
\text { relating to interests of } \\
\text { employees. }\end{array}$ & 3.29 & Fairly Agree \\
\hline $\begin{array}{l}\text { 4. I am provided with } \\
\text { the necessaries to } \\
\text { enhance the level of my } \\
\text { job efforts. }\end{array}$ & 3.61 & Agree \\
\hline $\begin{array}{l}\text { 5. I think my work } \\
\text { effort is recognized and } \\
\text { appreciated by my } \\
\text { manager/supervisor. }\end{array}$ & 3.25 & Fairly Agree \\
\hline Total & 3.40 & Fairly Agree \\
\hline
\end{tabular}

Job satisfaction has certainly or fairly positively affected the employee's happiness (fairly agree) that has a mean of 3.40. This implies that employees in oil and gas are somewhat satisfied with their current job as a whole. This is maybe due to the oil and gas industry worldwide nowadays are reviving and going back in times where there is stability.

Table 12: Career Advancement

\begin{tabular}{|c|c|c|}
\hline Items & $\begin{array}{c}\text { Mea } \\
\text { n }\end{array}$ & $\begin{array}{c}\text { Verbal } \\
\text { Interpretation }\end{array}$ \\
\hline $\begin{array}{c}\text { 1. I have opportunities } \\
\text { for my career growth. }\end{array}$ & 3.28 & Fairly Agree \\
\hline $\begin{array}{l}\text { 2. I believe that my work } \\
\text { contributes to the success } \\
\text { of the company. }\end{array}$ & 3.64 & Agree \\
\hline $\begin{array}{l}\text { 3. I am well-prepared in } \\
\text { any task they ask me. }\end{array}$ & 3.13 & Fairly Agree \\
\hline $\begin{array}{l}\text { 4. My work consistently } \\
\text { causes me to develop my } \\
\text { talents and abilities. }\end{array}$ & 2.61 & Fairly Agree \\
\hline $\begin{array}{l}\text { 5. I regularly meet my } \\
\text { task commitments in terms } \\
\text { of deadlines to have quality } \\
\text { work }\end{array}$ & 3.27 & Fairly Agree \\
\hline Total & $\mathbf{3 . 1 9}$ & $\begin{array}{c}\text { Fairly } \\
\text { Agree }\end{array}$ \\
\hline
\end{tabular}

It is certainly or fairly positively affected the employee's happiness in career advancement factor that has a mean of 3.19. This means employees see that there are opportunities in career advancement in their current organization. This can be the effect of having enough training and other skill development that could lead to career advancement.

Table 13: Role Alignment

\begin{tabular}{|c|c|c|}
\hline Items Mean & $\begin{array}{c}\text { Verbal } \\
\text { Interpretat } \\
\text { ion }\end{array}$ \\
\hline $\begin{array}{l}\text { 1. I don't feel physically tired } \\
\text { because of my unrelated } \\
\text { workload. }\end{array}$ & 4.28 & Agree \\
\hline $\begin{array}{l}\text { 2. It's easy for me } \\
\text { concentrate at work even if I } \\
\text { have other workload that is not } \\
\text { part of my job. }\end{array}$ & 4.34 & Agree \\
\hline $\begin{array}{l}\text { 3. My work is aligned with } \\
\text { the missions of the company. }\end{array}$ & 4.62 & Agree \\
\hline $\begin{array}{l}\text { 4. My workload is sufficient } \\
\text { to do my work well. }\end{array}$ & 4.69 & Agree \\
\hline $\begin{array}{c}\text { 5. I am satisfied with my } \\
\text { current job responsibilities. }\end{array}$ & 3.57 & Agree \\
\hline Total & $\mathbf{4 . 3 0}$ & Agree \\
\hline
\end{tabular}

Role Alignment factor has a mean of 4.30 and explained that this factor has positively affected the employee's happiness to the average extent. This high score of role alignment is evidence that people in this industry are consistently doing a great job with their job designation. Also, the HR are doing great job to hire enough person that would create enough manpower to minimize job overload to employees. 
Table 14: Relationship with Superiors

\begin{tabular}{|c|c|c|}
\hline Items & Mea & $\begin{array}{c}\text { Verbal } \\
\text { Interpretation }\end{array}$ \\
\hline $\begin{array}{c}\text { 1. My superiors treat } \\
\text { employees with respect. }\end{array}$ & 3.26 & Fairly Agree \\
\hline $\begin{array}{c}\text { 2. My superiors manifest } \\
\text { good leadership in leading } \\
\text { the team. }\end{array}$ & 3.87 & Agree \\
\hline $\begin{array}{l}\text { 3. My superiors appear to } \\
\text { be honest with employees. }\end{array}$ & 2.64 & Fairly Agree \\
\hline $\begin{array}{l}\text { 4. My superior constantly } \\
\text { trusts me to do good work } \\
\text { without feeling a need to } \\
\text { closely monitor my daily } \\
\text { task. }\end{array}$ & 3.28 & Fairly Agree \\
\hline $\begin{array}{l}\text { 5. My superiors give me } \\
\text { useful feedback on my job } \\
\text { performance. }\end{array}$ & 3.17 & Fairly Agree \\
\hline Total & $\mathbf{3 . 2 4}$ & $\begin{array}{c}\text { Fairly } \\
\text { Agree }\end{array}$ \\
\hline
\end{tabular}

Relationship with Superiors has a mean of 3.24 that fall in fairly agree which means that this factor has certainly or fairly positively affected the employee's happiness. According to Lee , respectful treatment of all employees at all levels was rated as very important by $67 \%$ of employees in 2015, making it the top contributor to overall employee job satisfaction for the second year in a row

Table 15: Working Environment

\begin{tabular}{|c|c|c|}
\hline Items & Mean & $\begin{array}{c}\text { Verbal } \\
\text { Interpretation }\end{array}$ \\
\hline $\begin{array}{l}\text { 1. My company is a safe } \\
\text { place to work. }\end{array}$ & 2.10 & Disagree \\
\hline $\begin{array}{l}\text { 2. I am aware of the risk } \\
\text { and hazards of my work } \\
\text { environment. }\end{array}$ & 3.11 & Fairly Agree \\
\hline $\begin{array}{l}\text { 3. I am comfortable in } \\
\text { my working area. }\end{array}$ & 2.52 & Disagree \\
\hline $\begin{array}{l}\text { 4. My working } \\
\text { environment gives meaning } \\
\text { in my career growth. }\end{array}$ & 2.51 & Fairly Agree \\
\hline $\begin{array}{c}\text { 5. There is a flexibility } \\
\text { in my work environment. }\end{array}$ & 2.32 & Disagree \\
\hline Total & $\mathbf{2 . 5 1}$ & Fairly Agree \\
\hline
\end{tabular}

With regards to working environment factor it has a mean of 2.93 and reflects that fairly agree which means that this factor has certainly or fairly positively affected the employee's happiness. Since oil and gas industry considered to have high risk job because of the different hazard involve.

Table 16: Meaningfulness of Work

\begin{tabular}{|c|c|c|}
\hline Items & Mea & $\begin{array}{c}\text { Verbal } \\
\text { Interpretation }\end{array}$ \\
\hline $\begin{array}{c}\text { 1. I am passionate doing } \\
\text { my current job }\end{array}$ & 2.56 & Fairly Agree \\
\hline $\begin{array}{c}\text { 2. I'm proud of my work } \\
\text { as }\end{array}$ & 3.07 & Fairly Agree \\
\hline $\begin{array}{l}\text { 3. My work provides } \\
\text { opportunity for career } \\
\text { advancement in the company }\end{array}$ & 3.11 & Fairly Agree \\
\hline
\end{tabular}
their happiness. for their employees.

In meaningfulness of work, it has fairly positively affected employee's happiness with a mean of 2.94. This means employees in oil and gas industry have fair understanding on the purpose of their job. Company should be involved in a more significant and positive contributions to the meaningfulness of people's lives to be able increase

Table 17: Summary of Internal Factors

\begin{tabular}{|l|c|c|}
\hline Items & Mean & $\begin{array}{c}\text { Verbal } \\
\text { Interpretation }\end{array}$ \\
\hline 1. Job Satisfaction & 3.40 & Fairly Agree \\
\hline 2. Career Advancement & 3.14 & Fairly Agree \\
\hline 3. Role Alignment & 4.30 & Agree \\
\hline 4. Working Environment & 2.51 & Fairly Agree \\
\hline $\begin{array}{l}\text { 5. Relationship with } \\
\text { Superiors }\end{array}$ & 3.24 & Fairly Agree \\
\hline $\begin{array}{c}\text { 6. Meaningfulness of } \\
\text { Work }\end{array}$ & 2.94 & Fairly Agree \\
\hline Total & $\mathbf{3 . 2 5}$ & $\begin{array}{c}\text { Fairly } \\
\text { Agree }\end{array}$ \\
\hline
\end{tabular}

In terms of internal factors of employee's happiness, the average mean is 3.32 which mean they are certainly or fairly positively affected in employee's happiness. In year 2015, large companies like Google have made substantial investments in the well-being of their workers. Finding causal relations between employee well-being and company performance is important for firms to justify spending corporate resources to provide a happier work environment

Table 18: Quality of Work

\begin{tabular}{|l|l|l|}
\hline Items & Mean & $\begin{array}{l}\text { Verbal } \\
\text { Interpretation }\end{array}$ \\
\hline $\begin{array}{l}\text { 1. My work is consistently } \\
\text { error free, thorough, neat, } \\
\text { correct, logically organized } \\
\text { and statistically accurate. }\end{array}$ & 4.12 & Agree \\
\hline $\begin{array}{l}\text { 2. My work contains some } \\
\text { acceptable errors that may } \\
\text { require some review and } \\
\text { editing by supervisor }\end{array}$ & 3.65 & Agree \\
\hline $\begin{array}{l}\text { 3. My work reflects errors } \\
\text { that require careful review } \\
\text { and correction by } \\
\text { supervisor or partial } \\
\text { reworking/revision. }\end{array}$ & 3.47 & Fairly Agree \\
\hline $\begin{array}{l}\text { 4. My job lets me use my } \\
\text { skills and abilities }\end{array}$ & 4.11 & Agree \\
\hline $\begin{array}{l}\text { 5. Conditions on my job } \\
\text { allow me to be about as } \\
\text { productive as I could be }\end{array}$ & 3.87 & Agree \\
\hline TOTAL & $\mathbf{3 . 8 4}$ & Agree \\
\hline
\end{tabular}


In this table, the respondents agreeing on the current quality of their work with the weighted mean of 3.84 . Employees assessed their quality of work by evaluating how they perform their job. The results show that employees in oil and gas are positive and confident in performing their work with high quality. This is credited to good leadership and training by the company since according to Gupta and Sharma, many factors add to increase the quality of work which incorporates sufficient and reasonable compensation, sheltered and healthy working conditions and social mix in the work association that empowers a person to create and utilize all his or her abilities.

In this table, it represents that the respondents are fairly agreeing on their working relationship with the weighted mean of 3.11. This score represents good working relationship of employees in oil and gas industry. Oil and gas industries requires good working relationship to be able to execute difficult and challenging jobs. Teamwork has been also known as a motive of job satisfaction as almost all works on job satisfaction and team performance matters, have figured job satisfaction as an outcome of team effectiveness. The very approach on job satisfaction as an outcome of team working and team effectiveness has necessitated the focus on the contributions of job satisfaction towards team working and willingness to work in teams.

Table 19: Working Relationship

\begin{tabular}{|l|l|l|}
\hline Items & Mean & $\begin{array}{l}\text { Verbal } \\
\text { Interpretation }\end{array}$ \\
\hline $\begin{array}{l}\text { 1. I am eager to leam on } \\
\text { ways of making ourselves } \\
\text { more productive }\end{array}$ & 4.32 & Agree \\
\hline $\begin{array}{l}\text { 2. I am able to identify and } \\
\text { give top attention to top } \\
\text { priorities }\end{array}$ & 3.01 & Fairly Agree \\
\hline $\begin{array}{l}\text { 3. I have a sense of what to } \\
\text { do and when to do }\end{array}$ & 3.67 & Agree \\
\hline $\begin{array}{l}\text { 4. I am able to deliver under } \\
\text { less than perfect } \\
\text { conditions }\end{array}$ & 3.44 & Fairly Agree \\
\hline $\begin{array}{l}\text { 5. I am able to generate } \\
\text { more than an hours' worth of } \\
\text { productivity of each hour }\end{array}$ & 3.03 & Fairly Agree \\
\hline TOTAL & $\mathbf{3 . 5 0}$ & Agree \\
\hline
\end{tabular}

Table 20: Time Management

\begin{tabular}{|l|l|l|}
\hline Items & Mean & $\begin{array}{l}\text { Verbal } \\
\text { Interpretatio } \\
\mathbf{n}\end{array}$ \\
\hline $\begin{array}{l}\text { 1. I have exceptional ability to } \\
\text { balance prionities effectively }\end{array}$ & 3.04 & Fairly Agree \\
\hline $\begin{array}{l}\text { 2. I consistently grasps what } \\
\text { takes precedence and works on } \\
\text { what is most urgently needed }\end{array}$ & 3.62 & Agree \\
\hline $\begin{array}{l}\text { 3. I meet schedules and } \\
\text { deadlines }\end{array}$ & 3.17 & Fairly Agree \\
\hline $\begin{array}{l}\text { 4. I work on the highest } \\
\text { priority tasks throughout the } \\
\text { day }\end{array}$ & 2.81 & Fairly Agree \\
\hline $\begin{array}{l}\text { 5. I use goal setting to } \\
\text { determine my most important } \\
\text { activities }\end{array}$ & 4.27 & Agree \\
\hline \begin{tabular}{l} 
TOTAL \\
\hline
\end{tabular} & $\mathbf{3 . 3 8}$ & Fairly Agree \\
\hline
\end{tabular}

In this table, it represents the status of time management of the respondents; it shows that they are fairly agreeing on the said factor with weighted mean of 3.38. Employees in this industry believe that they manage their time well especially in performing their task. Employees are confident that they can finish their job in the specified time that the organization have given. This is also due to many factors such as good leadership, training and motivation that have given by the company. In productivity of work, the respondents are agreeing on their work to make them productive with the weighted mean of 3.50. This means that respondents believe that they are being productive based on the task designated to them by the company.

Table 21: Productivity of Work

\begin{tabular}{|l|l|l|}
\hline Items Mean & $\begin{array}{l}\text { Verbal } \\
\text { Interpretatio } \\
\text { n }\end{array}$ \\
\hline $\begin{array}{l}\text { l. I tend more towards } \\
\text { being outgoing or more } \\
\text { reserved. }\end{array}$ & 3.15 & Fairly Agree \\
\hline $\begin{array}{l}\text { 2. I am enthusiastic in my } \\
\text { relations with others. }\end{array}$ & 3.07 & Fairly Agree \\
\hline $\begin{array}{l}\text { 3. I have been described as } \\
\text { high spirited by others. }\end{array}$ & 2.89 & Fairly Agree \\
\hline $\begin{array}{l}\text { 4. I like to be in control in } \\
\text { relationships. }\end{array}$ & 3.78 & Agree \\
\hline $\begin{array}{l}\text { 5. I work towards } \\
\text { co-operative relationships } \\
\text { with others. }\end{array}$ & 2.66 & Fairly Agree \\
\hline \begin{tabular}{l} 
TOTAL -- - - - - \\
\hline
\end{tabular} & 3.11 & Fairly Agree \\
\hline
\end{tabular}

Table 22: Summary of Performance Factor

\begin{tabular}{|l|l|l|}
\hline & Mean & $\begin{array}{l}\text { Verbal } \\
\text { Interpretation }\end{array}$ \\
\hline Quality of Work & 3.85 & Agree \\
\hline Working Relationship & 3.11 & Fairly Agree \\
\hline Time Management & 3.38 & Fairly Agree \\
\hline Productivity & 3.51 & Agree \\
\hline & & \\
\hline
\end{tabular}

In order to understand the relationship between the identified internal and external factors that affecting happiness of employees against their productivity, a t-test was run on a sample of 379 employees in oil and gas industry to determine whether there was a statistically significant mean relationship between:

1. External Factors of Happiness vs Productivity, and

2. Internal Factors of Happiness vs Productivity. 
Table 23: External vs Productivity (T-test)

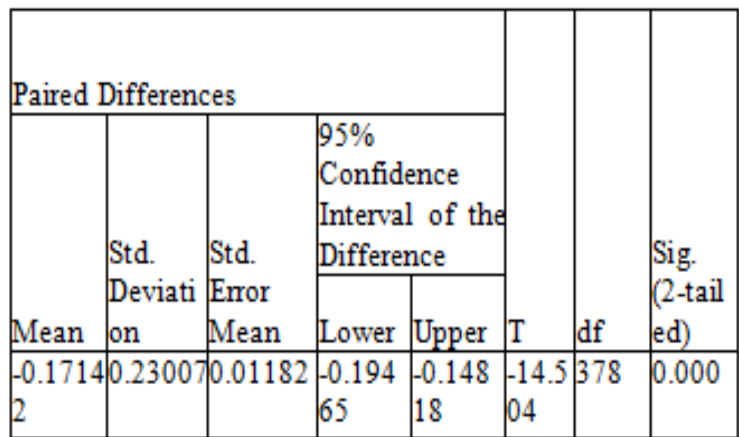

Results showed participants external factors mean score (mean=3.2916, $\mathrm{SD}=0.20667$ ) has small difference on the overall productivity mean score (mean=3.4631, SD= 0.21702). The t-test shows that at $95 \%$ confident interval, external factors of happiness has a statistically significant effect on the mean productivity score $(\mathrm{t}=-14.504, \mathrm{df}=378$, $\mathrm{P}<0.001)$

Table 24: External vs Performance (correlation)

\begin{tabular}{|l|l|l|l|l|}
\hline \multicolumn{2}{|l|}{} & $\mathrm{N}$ & Correlatio & Sig. \\
\hline Pair 1 & $\begin{array}{l}\text { OVERALL } \\
\text { EXTERNAL } \\
\text { MEAN } \\
\text { OVERALL } \\
\text { OV } \\
\text { PRODUCTIVIT } \\
\text { Y }\end{array}$ & 379 & 0.411 & 0.000 \\
\hline
\end{tabular}

Table 21 shows that the degree of correlation between external factors and performance is strong with a value of 0.411 .

Table 25: Internal vs Productivity (T-test)

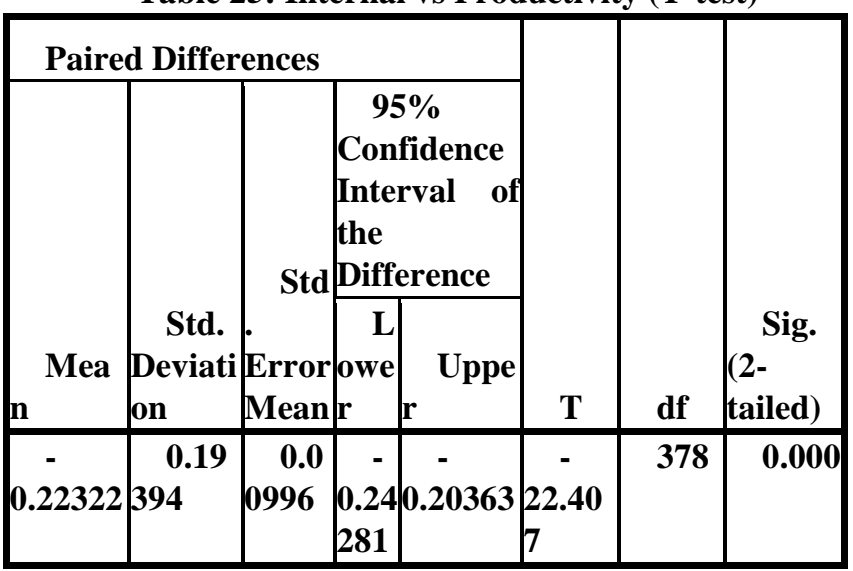

Results showed participants internal factors mean score (mean=3.2398, $\mathrm{SD}=0.15840$ ) has small difference on the overall productivity mean score (mean $=3.4631, \mathrm{SD}=$ 0.21702 ). The paired t-test shows that at $95 \%$ confident interval, internal factors of happiness has a statistically significant effect on the mean productivity score $(\mathrm{t}=$ $-22.407, \mathrm{df}=378, \mathrm{P}<0.001)$. Table 23 shows that internal factors have also strong correlation of 0.503 .

Table 26: Internal vs Productivity (T-test)

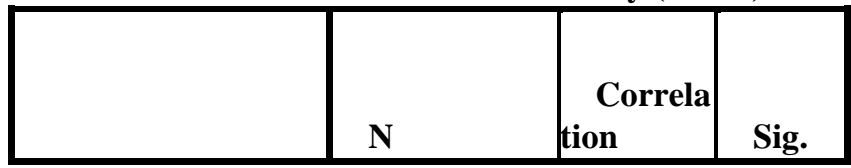

\begin{tabular}{|cc|l|l|l|}
\hline Pai & OVERALL & 379 & 0.503 & 0.000 \\
r 1 & INTERNAL & & & \\
& MEAN \& \\
OVERALL & & & & \\
& & & \\
\hline & PRODUCTIV & & & \\
ITY & & & \\
\hline
\end{tabular}

\section{CONCLUSION}

The need to understand, improve and gain information on the factors affecting happiness of employees in oil and gas industry was the primary objective of the study. The study examined the relationship between factors of happiness and productivity using T-test with $95 \%$ confidence level. The findings show that the employees had a higher level of happiness level. The study also shows that both internal and external factor of happiness are statistically significant with productivity and both internal and external factor of happiness is positively related to productivity. The analysis of the findings of the study allows the researcher to make a few necessary recommendations, which could be assessed and implemented by the oil and gas companies in UAE to assess the rate of employee's happiness. Researches concerning happiness and productivity are clearly becoming more significant. Study on employees' happiness has recently gained much attention due to its emphasis in organizational studies and the impact it has on overall employee performance (Gupta, 2012). The focus of the study, accordingly, has been to identify the factors that affect the employee's happiness and subsequently relate these identified factors to the employee's productivity in an oil and gas industry in Abu Dhabi, UAE. Early investigation focused on the factors that generally affects both happiness and performance of employees by reading different literatures. After identifying these factors, being able to develop a correct survey questionnaire to show evidence that could lead correct analysis of the variables. The research found out that both factors affecting happiness have significant relation to employee's performance or productivity. The employee's performance is positively related to their happiness. Which supports with most of the related literatures. Knowledge concerning on these factors is essential to companies that could use to enhanced productivity of their employees and to retain skilled workforce of the organization.

\section{LIMITATION OF THE STUDY}

One of the limitations of the present study is that, it is based on external and internal factors, there were more variables that could be considered as the indicators of employee's happiness and productivity yet the present study could work on some of them as the literature supported these factors more extensively. However, working on the rest of the factors that are suggested could probably predict a greater consistency of employees' happiness. On the other hand, lack of recent literature about the listed internal, 
external, performance evaluation and productivity of work factors of happiness in work and the relationship between factors and demographic profiles was also another limitation.

\section{RECOMMENDATION OF THE STUDY}

Most of the work of this paper is theoretical but a complete mathematical model to measure this happiness and productivity can be done in future research. The study showed that top 3 factors that may affect the employee's happiness that companies can use and develop programs. Organization could develop model and programs considering these factors though there are still many factors to consider such as; relationships among wage and salary structure, compensations, fringe benefits, location advantage, job security, social and economic factors etc. To integrate all these factors in a model could show a new way to control employee's happiness and its productivity. In further studies however, collecting data focusing on specific oil and gas location in which most of the oil and gas industry have different location to cater different type of business like on-shore, off shore, city based and would improve the research mores. This will also become an important tool and knowledge on how to improve programs of the company to increase employee's happiness. Also, it would broaden the contributions of the study if both employees and employers are considered rather than focusing on selected employees only

\section{REFERENCES}

1. Uchida Y, Oishi S. The happiness of individuals and the collective. Japanese Psychological Research. 2016 Jan;58(1):125-41.

2. Gupta V. Importance of being happy at work. International Journal on Research and Development: A Management Review. 2012;1(1):9-14.

3. Wesarat PO, Sharif MY, Majid AH. A conceptual framework of happiness at the workplace. Asian Social Science. 2015 Jan 1;11(2):78.

4. Diener E. Subjective well-being: The science of happiness and a proposal for a national index. American psychologist. $2000 \mathrm{Jan} ; 55(1): 34$.

5. Lyubomirsky S, King L, Diener E. The benefits of frequent positive affect: Does happiness lead to success?. Psychological bulletin. 2005 Nov;131(6):803.

6. Fredrickson BL, Branigan C. Positive emotions broaden the scope of attention and thought-action repertoires. Cognition \& emotion. 2005 Mar 1;19(3):313-32.

7. Lyubomirsky S, King L, Diener E. The benefits of frequent positive affect: Does happiness lead to success? Psychological bulletin. 2005 Nov;131(6):803.

8. Chiumento S. Happiness at work index. London: Chiumento. 2007.

9. Aldehayyat JS, Al Khattab AA, Anchor JR. The use of strategic planning tools and techniques by hotels in Jordan. Management Research Review. 2011 Mar 29;34(4):477-90.

10. Team T. As a rare profitable unicorn, Airbnb appears to be worth at least $\$ 38$ billion. Forbes, May. 2018 May;11.

11. De Rubeis S, Buxbaum JD. Genetics and genomics of autism spectrum disorder: embracing complexity. Human molecular genetics. 2015 Jul 17;24(R1):R24-31.

12. Diener E. Subjective well-being: The science of happiness and a proposal for a national index. American psychologist. 2000 Jan;55(1):34.
13. Abrahamsson P, Salo O, Ronkainen J, Warsta J. Agile software development methods: Review and analysis. arXiv preprint arXiv:1709.08439. 2017 Sep 25.

14. Johnson K. An introduction to foreign language learning and teaching. Routledge; 2017 Nov 22.

15. Gallup LL. State of the American workplace: Employee engagement insights for US business leaders. Retrieved from Washington, DC: http://www. gallup. com. 2013.

16. Miles BN, Ivanov AP, Wilson KA, Doğan F, Japrung D, Edel JB. Single molecule sensing with solid-state nanopores: novel materials, methods, and applications. Chemical Society Reviews. 2013;42(1):15-28.

17. Halvorson H. The semantic view, if plausible, is syntactic. Philosophy of Science. 2013 Jul 1;80(3):475-8.

18. Manokaran K, Ramakrishnan S, Hishan S, Soehod K The impact of corporate social responsibility on financial performance: Evidence from Insurance firms. Management Science Letters. 2018;8(9):913-32.

19. Miner AG, Glomb TM. State mood, task performance, and behavior at work: A within-persons approach. Organizational Behavior and Human Decision Processes. 2010 May 1;112(1):43-57.

20. Fisher R, Salanova V, Witt T, Worth R, Henry T, Gross R, Oommen K, Osorio I, Nazzaro J, Labar D, Kaplitt M. Electrical stimulation of the anterior nucleus of thalamus for treatment of refractory epilepsy. Epilepsia. 2010 May;51(5):899-908.

21. Hosie PJ, Sevastos P. Does the "happy-productive worker" thesis apply to managers?. International Journal of Workplace Health Management. 2009 Jun 26;2(2):131-60.

22. Meyer E, Carss KJ, Rankin J, Nichols JM, Grozeva D, Joseph AP, Mencacci NE, Papandreou A, Ng J, Barral S, Ngoh A. Mutations in the histone methyltransferase gene KMT2B cause complex early-onset dystonia. Nature genetics. $2017 \mathrm{Feb}$;9(2):223.

23. Seligman ME. Positive psychology, positive prevention, and positive therapy. Handbook of positive psychology. 2002 May;2(2002):3-12.

24. Hawker S, Waite M, editors. Compact Oxford thesaurus for university and college students. Oxford Univ Pr; 2007 Sep 16.

25. Alsolami B, Embi MR, Enegbuma WI. The influence of personal factors on Hajj crowd perception among African Pilgrim Group in Mina. Indian Journal of Science and Technology. 2016 Dec;9(9).

26. Veenhoven R. Inequality of happiness in nations. Journal of Happiness Studies. 2005 Dec 1;6(4):351-5.

27. Levett-Jones T, Hoffman K, Dempsey J, Jeong SY, Noble D, Norton CA, Roche J, Hickey N. The 'five rights' of clinical reasoning: An educational model to enhance nursing students' ability to identify and manage clinically 'at risk'patients. Nurse education today. 2010 Aug 1;30(6):515-20.

28. Bekhet AK, Zauszniewski JA. Methodological triangulation: An approach to understanding data. Nurse researcher. 2012.

29. Lyubomirsky S, Boehm JK. Human motives, happiness, and the puzzle of parenthood: Commentary on Kenrick et al.(2010). Perspectives on Psychological Science. 2010 May;5(3):327-34.

30. LeBreton JM, Hargis MB, Griepentrog B, Oswald FL, Ployhart RE. A multidimensional approach for evaluating variables in organizational research and practice. Personnel Psychology. 2007 Jun;60(2):475-98.

31. Barmby T. CEP Discussion Paper No 1151 June 2012 Human Capital, Matching and Job Satisfaction Tim 
Barmby, Alex Bryson and Barbara Eberth.

32. Pryce-Jones J, Scott DE. Keeping happy at work during economic turmoil. Tar heel nurse. 2009;71(4):18-9.

33. Active E. Deloitte (2017). European Health \& Fitness Market Report 2017. 2017.

34. Maceda-Veiga A, Figuerola J, Martínez-Silvestre A, Viscor G, Ferrari N, Pacheco M. Inside the Redbox: applications of haematology in wildlife monitoring and ecosystem health assessment. Science of the Total Environment. 2015 May 1;514:322-32.

35. Gupta A, Mathur S, Krongold Y, Nicastro F, Galeazzi M. A huge reservoir of ionized gas around the Milky Way: accounting for the missing mass?. The Astrophysical Journal Letters. 2012 Aug 9;756(1):L8.

36. Jurgensen CE. Job preferences (What makes a job good or bad?). Journal of Applied psychology. 1978 Jun;63(3):267.

37. Caporale GM, Georgellis Y, Tsitsianis N, Yin YP Income and happiness across Europe: Do reference values matter?. Journal of Economic Psychology. 2009 Feb 1;30(1):42-51.

38. Frey BS, Stutzer A. What can economists learn from happiness research?. Journal of Economic literature. 2002 Jun;40(2):402-35.

39. Smith PC, Kendall LM, Hulin C. The measurement of satisfaction in work and behavior. Chicago: Raud McNally. 1969.

40. Gedefaw K. Job satisfaction of secondary school teachers in Ethiopia. University of South Africa $(\mathrm{PhD}$, Dissertation). 2012.

41. Holly, Sarah, and Alwine Mohnen. "Impact of working hours on work-life balance." (2012).

42. Paul S, Guilbert D. Income-happiness paradox in Australia: Testing the theories of adaptation and social comparison. Economic Modelling. 2013 Jan 1;30:900-10.

43. Asiyabi M, Mirabi V. Investigation of contributing factors in employees desertion in power engineering consultants (Moshanir) company. Interdisciplinary Journal of Contemporary Research in Business. 2012;4(6):1183-99.

44. Jones C. Networks and learning: communities, practices and the metaphor of networks - a response. ALT-J. 2004 Jun 1;12(2):195-8.

45. Shelton, Nicola, Caitríona Ní Laoire, Shaun Fielding, David Harvey, Mark Pelling, and Oliver Duke-Williams. "Working at the coalface: contract staff, academic initiation and the RAE." (2001)

46. Sahinidis AG, Bouris J. Employee perceived training effectiveness relationship to employee attitudes. Journal of European Industrial Training. 2008 Jan 25;32(1):6376.

47. Robbin SP, Odendaal A, Roodt G. Organisational behavour: Global and Southern African perspective. Cape Town: Pearson Education South Africa. 2003.

48. Herzberg FM, Mausner B. B. \& Snyderman, B.(1959). The motivation to work. 1959;2:49-58.

49. Abduljabbar WK, Tahar RM. A case study of petroleum transportation logistics: A decision support system based on simulation and stochastic optimal control. African Journal of Business Management. 2012 Mar 21;6(11):4350-61.

50. Ryan RM, Deci EL. Intrinsic and extrinsic motivations: Classic definitions and new directions. Contemporary educational psychology. 2000 Jan 1;25(1):54-67

\section{AUTHORS PROFILE}

Naser Yassin Al Hammadi, Faculty of Technology Management and Business, Universiti Tun Hussein Onn Malaysia, 86400 Parit Raja, Batu Pahat, Johor, Malaysia
.Md Asrul Nasid Bin Masrom, Department of Construction Management, Faculty of Technology Management and Business, Universit Tun Hussein Onn Malaysia, 86400 Parit Raja, Batu Pahat, Johor, Malaysia

Sulzakimin Mohamed, Department of Construction Management, Faculty of Technology Management and Business, Universiti Tun Hussein Onn Malaysia, 86400 Parit Raja, Batu Pahat, Johor, Malaysia. 